\title{
Letter from the Editor-in-Chief
}

\author{
Peter G. M. de Jong ${ }^{1}$
}

Published online: 4 August 2015

(C) International Association of Medical Science Educators 2015

Welcome to the third issue of Medical Science Educator in 2015. I am happy to present to you several manuscripts reporting on medical education which I hope will be of interest to you.

It has only been several weeks since IAMSE had the annual meeting, this time in San Diego (USA). It was a pleasure meeting with so many of you and listening to so many interesting presentations. As usual an extra edition of our journal focusing on this meeting will be published later this year.

In the current issue, a new feature of the journal is being introduced: "journal sections" on a specific topic. These thematic sections are the successor of the special issues we

published in the past. I know that many of you appreciated and enjoyed these supplements, and therefore we transformed them into journal sections. The theme for 2015 is Integration and in this issue, the first three articles are published. Please see the introduction page later in this issue.

I hope you will enjoy this issue and that you will continue supporting Medical Science Educator both as a reader and as an author of your own scholarly work for the benefit of our work and the work of others!

Peter G.M. de Jong, Ph.D.

Editor-in-Chief

Peter G. M. de Jong

P.G.M.de_Jong@lumc.nl

1 Leiden University Medical Center, Leiden, The Netherlands 